\title{
A location for "Atlantis"?
}

\section{Rainer W. Kühne}

The location and reality of Atlantis continues to invite speculation reasoned or otherwise. Some recent scientific articles have argued for historical elements in Plato's Atlantis tale. For example the possibility that it my have referred to Troy has been raised and rejected (Zangger 1993, Renfrew 1992, Bloedow \& Spina 1994); while for others the place mentioned by Plato is simply fiction (Nesselrath 2001a,b). In two recent articles $(2001,2002)$, Professor Collina-Girard of the University of Aixen-Provence suggests that this Atlantis can be identified with Spartel Island which is located at $35^{\circ} \mathrm{E} 55^{\prime} \mathrm{N}$ and $5^{\circ} \mathrm{E} 58^{\prime} \mathrm{W}, 50$ kilometres to the west of the present Strait of Gibraltar at a depth of $56 \mathrm{~m}$ below the surface. Professor Collina-Giraud had planned an expedition to Spartel island which was briefly noted in the press. This short note questions the identification of Spartel with "Atlantis" but proposes that nevertheless the place mentioned by Plato does not have to be entirely fictional. The Platonic accounts may have been referring to events which took place in the SW of the Iberian peninsula at the end of the Bronze Age.

\section{Atlantis as Spartel}

In his dialogues "Timaios" and "Critias" Plato described the island state of Atlantis which was defeated by the Athenians in a war (Crit. 108e) and which soon afterwards sank into the sea as a result of earthquakes and floods (Tim. 25c - d, Crit. 108e). Atlantis lay in front of the pillars of Heracles (Tim. 24e) and from it one could travel to other islands (Tim. 24e). It had sunk into the sea approximately 9000 years before Plato's dialogue (Crit. 108e; Tim. 25d). There existed three islands in the neighbourhood of Spartel Island, one to the north and two to the east. The tops of these islands are now 50 to 100 metres below sea level. These islands disappeared underwater in about $9000 \mathrm{BC}$ as a result of the eustatic rise in the level of the sea. There are a number of problems identifying Atlantis with Spartel. For example, at the former location of Atlantis the sea was described as unnavigable and impenetrable (Tim. 25d), because of thick mud (Crit. 108e - 109a). Today, shoal water exists for some 40 kilometres in the north-west of Spartel Island. The size of the plain of Atlantis was 
said to be 3000 stades (550 kilometres) by 2000 stades (370 kilometres) (Crit. 118a, c) and lay on the southern part of the island (Crit. 118a - b) surrounded by mountains (Crit. 118b) which reached to the sea (Crit. 118a). Apart from this, the country was very high and had a steep coast (Crit. 118a). The Atlantean capital is described as lying on a flat hill (Crit. 115c) on the edge of a smooth and even rectangular plain (Crit. 113c) 50 stades (9 kilometres) distant from the sea .

By contrast, even during the Late Glacial Maximum, 21000 - 19000 years ago, the size of Spartel Island was only 14 by 5 kilometres. The site is also inconsistent with the reported activities of the Atlanteans, and with the historical period about which Plato appears to be writing. In general, whatever the truth of the story, he was probably referring to a different area than Spartel and a much later period than the end of the ice age.

\section{Comparison of Atlantis and the Sea Peoples}

In his account of the Atlantean war Plato gives a description of the Athenian acropolis (Crit. 111e - 112e), which can be equated with its appearance in around $1200 \mathrm{BC}$. For example, Plato mentions the dwellings of warriors north of the acropolis (Crit. 112b) and a spring which was destroyed during earthquakes (Crit. 112d), which might be identified with the spring, destroyed by an earthquake discovered by Oskar Broneer (1939) and dated to the end of the thirteenth century BC. Marinatos (1950) and GÃ $\mid \tilde{A} \rrbracket$ rgemanns, (2000) have suggested that the Atlantean warriors can be identified with the Sea Peoples who were active in this period and are mentioned in inscriptions of the temple of Medinet Habu of around 1180 BC under Pharaoh Ramses III. This idea can be supported by comparison between Plato's description of the Atlanteans and the description of the Sea Peoples by Ramses III as given in the translations of Chabas (1872) and Edgerton and Wilson (1936) (see TABLE 1).

\section{A location on the Iberian peninsula?}

If an identification with the Sea Peoples is valid, then "Atlantis" should refer to their place of origin. There is some literary indication of where this might have been. Atlantis was divided under the ten sons of Poseidon (Crit. $113 \mathrm{e})$. The first born, Atlas, obtained the largest and best territory, namely the region around the capital (Crit. 114a). The second born, Gadeiros, obtained the part at the most distant edge which reached from the pillars of Heracles (Gibraltar) to the Gadeirean country (the region around Cadiz) (Crit. 114b). The part of the country belonging to Gadeiros was a coastal region 100 kilometres long. The parts of the later born sons were probably even smaller. Thus, the part of the country belonging to Atlas cannot have been very far from Cadiz. 
In fact, near Cadiz there is a rectangular, smooth and even plain which lies on the south coast at the mouth of the Guadalquivir River. It is the plain south-west of Seville through which the Guadalquivir river flows, and where the town of Tartessos was thought to have been located. Hennig (1925, 1927), Jessen (1925), and Schulten (1927, 1939) have all supposed that this was a possible location for Plato's Atlantis. In this respect, it is not without interest that large structures have been identified from recent satellite photos in this part of the lower Guadalquivir basin. One shows a rectangular structure with a length of 230 metres and a width of 140 metres. It could be a remnant of a temple of Poseidon, such as that whose length was one stade (185 metres) and whose width was three plethra (92 metres) (Crit. 116c - d). A further "quadratic" structure of size 280 metres times 240 metres could equate to the temple of Cleito and Poseidon (Crit. 116c ). The geographical co-ordinates of the rectangular structure are $36 \mathrm{E}^{\circ} 57^{\prime} 25^{\prime \prime}+/$ $6 " \mathrm{~N}$ and $6 \mathrm{E}^{\circ} 22^{\prime} 58^{\prime \prime}+/-8^{\prime \prime} \mathrm{W}$. The centre of the "quadratic" structure is 500 metres in the south-west of the centre of the rectangular structure. These structures lie in a mud region named "Marisma de Hinojos".within the Parque Nacional de Donana. of Andalusia

\section{Conclusion}

Plato's war between Atlantis and the Eastern Mediterranean countries finds echoes with the activities of the Sea Peoples around 1200 BC, and may be based on Egyptian reports and Greek traditions preserved in the Athens of his time. While a location on the sunken post-glacial island of Spartel is unlikely, there is a possibility that the city and society of Atlantis may refer to either Iron Age Tartessos or a Bronze Age culture in the same area of south-west Spain.

TABLE 1: Comparis on between Plato's description of the Atlanteans and the description of the Sea Peoples by Ramses III as given in the translations of Chabas (1872) and Edgerton and Wilson (1936). (here cited by plate and line number):

The Atlanteans fought against Europe and Asia (Tim. 24e) and "every country within the mouth", i. e. against the Eastern Mediterranean countries (Tim. 25b). The Sea Peoples destroyed Hatti in Anatolia, Qode and Qarkemish in northern Syria, Arzawa in south-west Anatolia, and Alasia on Cyprus (Plate 46.16 - 17) and fought against Egypt.

The Atlanteans lived on an isle (Tim. 24e, 25a, 25d, Crit. 113c) and reigned over several other islands (Tim. 25a). The Sea Peoples also came from islands 
(P1. 37.8 - 9, 42.3, 46.16).

The Atlanteans reigned in Africa from the pillars of Heracles (Gibraltar) to the frontiers of Egypt (Tim. 25 a - b). The war of the Sea Peoples against Egypt occurred simultaneously with the war of the Libyan Meshwesh. According to Ramses' report they appeared to be allied.

Atlantis consisted of ten countries (Crit. 113e-114a, 119b). According to the Karnak inscription (Chabas 1872, de Roug $\tilde{A}(\tilde{A}($ 1867) written under pharaoh Merenptah around $1200 \mathrm{BC}$, the Sea Peoples consisted of the Ekwesh, Teresh, Lukka, Sherden, and Shekelesh. According to Ramses III their confederation consisted of the union of the countries of the Peleset, Theker, Shekelesh, Denen, and Weshesh (P1.46).

In the case of war the Atlanteans had more than one million soldiers (Crit. 119a-b). Ramses III claimed to have beaten hundreds of thousands of enemies (P1. 18.16, 19.4 - 5, 27.63, 32.10, 79.7, 80.36, 80.44, $101.21,121 \mathrm{c} .7)$. Occasionally, he spoke of millions (P1. 27.64, 46.4, 46.6, 79.7, 101.21) and myriad (P1. 27.64) enemies who were numerous like locusts (P1. $18.16,80.36)$ or grasshoppers (P1. 27.63).

The Atlanteans had 1200 war ships (Crit. 119b). The ships of the Sea Peoples entered deep into the delta of the Nile (P1. 42.5) and destroyed the Asian Arzawa, the Cypric Alasia, and the near-eastern Ugarit and Amurru.

The Atlanteans had chariots pulled by horses (Crit. 119a). The Meshwesh had horses (P1.75.37) and carts (P1. 18.16, 75.27) which, however, were pulled by oxen (figures to $\mathrm{P} 1.32$ - 34).

The Atlantean kings reigned for several generations (Crit. 120d-e) and after this they lost their good attitudes (Crit. 121a-- b). Ramses III wrote about the Sea Peoples that they had spent a long time, a short moment was before them, then they entered the evil period (P1. 80.16 - 17).

During a day and a night Atlantis sank by a 
earthquake into the sea (Tim. $25 c-d$ ). Ramses III wrote that he let the Sea Peoples see the majesty and force of (the God of water) Nun when he breaks out and lays their towns and villages under a surge of water (Pl. 102.21), moreover the mountains were in travail (P1. 19.11).

\section{Acknowledgements}

I thank Werner Wickboldt for pointing out to me the structures on the satellite photos which he interpreted as possible remnants of the temples of Atlantis. I thank Georgeos Diaz-Montexano for showing me independent satellite photos which confirm the existence of the two rectangular structures.

\section{References}

- BLOEDOW, Edmund F. \& SPINA, Giuseppina A. (1994): "Two Tales of One City: Atlantis Surfaces from the Deluge to Claim Ilion", in: Studia Troica 4 (1994) 159-172.

- BRONEER, O. 1939 A Mycenaean Fountain on the Athenian Acropolis. Hesperia 8:317 - 429.

- CHABAS, F. 1872 Etudes sur l'Antiquité historique d'après les sources égyptiennes et les monuments réputés prehistoriques. Paris: Maisonneuve.

- COLLINA-GIRARD, J. 2001 L'Atlantide devant le dètroit de Gibraltar? Mythe et gèologie, C. R. de l'Academie des Sciences (2a) 333:233 - 240.

- COLLINA-GIRARD, J. 2002 La Crise Finiglaciaire \&grave; Gibraltar et l'Atlantide: Tradition orale et Géologie, Préhistoire Anthropologie Méditerranéennes T. 10 - 11:53 - 60.

- EDGERTON, W.F.\& J. A WILSON 1936 Historical Records of Ramses III. The Texts in Medinet Habu. Chicago: University of Chicago Press.

- GOORGEMANNS, Herwig (2000): "Wahrheit und Fiktion in Platons Atlantis-Ezäählung" in: Hermes 128 (2000) 405 - 419

- HENNIG, R. 1925 Das Rätsel der Atlantis. Meereskunde 14:1 - 29.

- HENNIG, R. 1927 Zum Verständnis des Begriffs "Säulen" in der antiken Geographie. Petermanns geographische Mitteilungen 73:80 87.

- JESSEN, O. 1925 Tartessos-Atlantis. Zeitschrift der Gesellschaft für Erdkunde 184.

- MARINATOS, S. 1950 Peri ton Thrulon tes Atlantidos. Kretica Chronica 4:195 - 213.

- MASPERO, G. 1873 Review of F. Chabas's Etudes. Revue Critique 
d'Histoire et de Littérature.

- NESSELRATH, Heinz Güünther 2001 a: "Atlantes und Atlantioi: Von Platon zu Dionysios Skytobrachion", Philologus 145, 34-38.

- NESSELRATH, Heinz Güünther 2001b: "Atlantis auf äägyptischen Stelen? Der Philosoph Krantor als Epigraphiker", Zeitschrift für Papyrologie und Epigraphik 135, 33-5

- RENFREW, Colin 1992: "Mere Platonic Invention?" Nature 356: 642.

- ROUGÉ, E. DE 1867 Extraits d'un mémoire sur les attaques dirigées contre l'Egypte par les peuples de la Méditerranee vers le XXVe siècle avant notre ère. Paris: Didier.

- SCHULTEN, A. 1927 Tartessos und Atlantis. Petermanns geographische Mitteilungen 73:284 - 288.

- SCHULTEN, A. 1939 Atlantis. Rheinisches Museum für Philologie $88: 326-346$.

- VENTRIS, M. \& J. CHADWICK 1953 Evidence for Greek Dialect in the Mycenaean Archives. Journal of Hellenic Studies 73:86 - 103.

- ZANGGER, Eberhard 1993: "Plato's Atlantis Account - A Distorted Recollection of the Trojan War", Oxford Journal of Archaeology 18: $77-87$

Rainer W. Kühne: Lechstr. 63, 38120 Braunschweig, Germany E-mail: kuehne70@gmx.de

\section{Previous Page}

\section{Home | Online Archive | Project Gallery | FAQs Letters to the Editor | Events and Announcements | Reviews I TAG

